\title{
Implementation Analysis of Solar PV Based SEPIC Inverter System
}

\author{
Saurabh Kumar ${ }^{1}$ Adeeb Uddin Ahmad ${ }^{2}$ | Neevatika Verma ${ }^{3}$ | Vikas Verma ${ }^{4}$ | Shweta Singh ${ }^{5}$ \\ 1,2Department of Electrical Engineering, Institute of Engineering \& Technology, Lucknow, India \\ ${ }^{3}$ Department of Electrical Engineering, Delhi Technological University, New Delhi, India \\ ${ }^{4}$ Department of Electrical Engineering, Kanpur Institute of Technology, Kanpur, India \\ ${ }^{5}$ Department of Electrical Engineering, UNS Institute of Engineering and Technology, VBSPU, Jaunpur,India
}

\section{To Cite this Article}

Saurabh Kumar, Adeeb Uddin Ahmad, Neevatika Verma, Vikas Verma and Shweta Singh. Implementation Analysis of Solar PV Based SEPIC Inverter System. International Journal for Modern Trends in Science and Technology 2021, 7 pp. 08-16. https://doi.org/10.46501/IJMTST0710002

\section{Article Info}

Received: 30 August 2021; Accepted: 24 September 2021; Published: 28 September 2021

\section{ABSTRACT}

For welfare of environment, world needs to use more and more renewable energy system not only at the level of industrial but also for domestic load system. Due to much installation cost involving in a solar PV cell/panel based system there is a need of better mechanisms to get maximum utilization and benefits from the system with reliable operation, especially in the case of microgeneration power plant to full fill the minimum desired requirements of domestic appliances to achieved reliable operation. Mostly available PV based inverter system having problem of low output voltage generation and THD producing issue, which needs to a requirements of extra circuit to the control THD and boost up the level of output voltage. In this paper, solar PV based closed loop SEPIC converter by PWM technique to maintain a step up constant dc output voltage with no polarity reversal, low ripple in output and minimizing the requirement of additional filter circuit and fed to single phase inverter. This paper has been focused for the overall single phase PV based SEPIC inverter system implementation, performances and simulated on MATLAB/SPS software to provide low losses, $2 \%$ minimum THD and reliable operation in compare with single phase PV based Cuk inverter is used for DC-AC conversion system to compatible with domestic load appliances.

KEYWORDS: Cuk converter, PID controller, Solar PV cell, SEPIC converter, Single phase full bridge VSI

\section{I.INTRODUCTION}

Due to rapid depletion of fossil fuels, the world needs a source of energy which are renewable in nature, so that it's full fills the needs of all civilization without affecting or producing the environmental problems and gives sustainability in the sector of power [1]. Energy is important in almost every aspect of our life and for the achievement of country economy [2]. As per the present and future expectation situation of power sector, usage of the renewable energy source and generating electricity from this is exponentially rising as a primary source for various types of applications such as industrial, non-commercial, service oriented, etc., as part of an approach to decrease the dependence on fossil fuels, large sized battery banks and central utility grid [3]. Also, the usage of renewable energy will support in addressing environmental effluences, transmission efficiencies, cost suffered in transmission, etc. [4-6]. Any electrical generation system must obey through certain quality principles and operation guidelines, mainly if there is any energy conversion in the electrical system [7]. The Earth have naturally different type of renewable source of energy such as Solar, fuel, Wind, biomass, biofuel, geothermal, hydro, 
tidal, wave, etc., which can be converted into electrical or any other form of energy directly or indirectly. Generally in comparison of other, the solar photovoltaic plants system consider the utility grid by way of vast storing system capable of absorb as much energy as preferred, with less maintenance of the electrical system for domestic load [8].

In Solar PV system, PV cell generate a low variable voltage due to variation in the solar radiations. The DC-DC converter is like a transformer for step up and step down the dc voltage level. In this paper, SEPIC power converter using PID controller is used to boost the input DC Voltage that is fed by Solar PV cell because its performance and efficiency are better than other converter like boost, cuk, etc., and also having advantage that do not required addition filter circuit, minimum ripple comparatively and do not invert the voltage at the output level [9]. The proposed efficient solar energy based DC-AC system as shown in Fig.1.

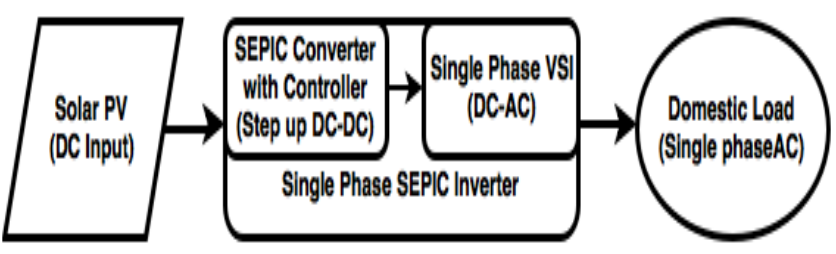

Fig.1. Block diagram of solar energy based DC-AC system.

For reliable control of the output of converter feedback techniques is used which overall creates a closed loop SEPIC converter for this system. The dc-dc converter based PV energy system is applied in various convenient applications so in this for domestic loads by converting DC voltage from SEPIC converter to AC voltage with the help of single phase full bridge VSI, so power that would be available at an electrical wall outlet.

\section{SOLAR PHOTOVOLTAIC CELL}

A solar cell is a PN junction with a large surface area and to allow light because of $\mathrm{N}$-type material generally thin. The electricity is generate in depletion zone when photon incident on the PN junction. For creating PN junction mainly silicon atom lattices are used. To form P-type and N-type material doping are done to create an excess holes and extra electrons respectively. When a photon of light is absorbed then holes of $\mathrm{P}$ region try to diffuse electrons of $\mathrm{N}$ region and vice versa and create a charge in junction which can produce electric field. The free hole and electron has enough energy to jump out of the depletion part zone. If an external load is connected with the help of wire to the PN junction. Thus electron is attracted to the positive charge of the P-type material and hole is attracted to the negative charge of the N-type material, so that current flows through the external load as show in Fig.2

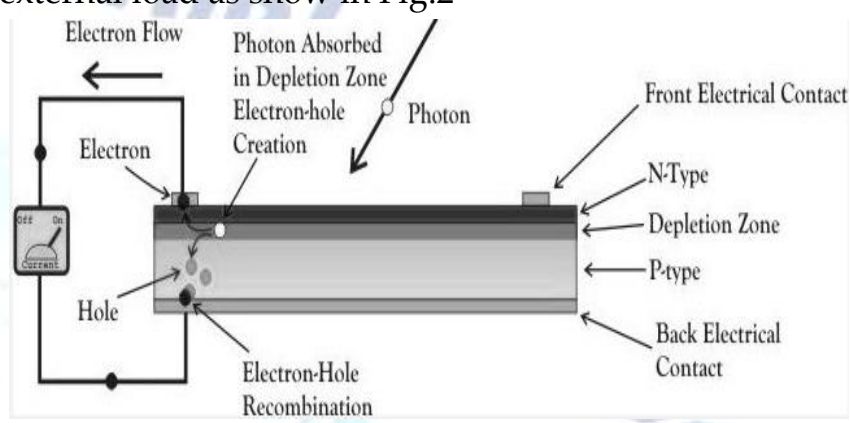

Fig.2. Diagram of electricity generation by solar PV cell

Equivalent Circuit of ideal solar cell is represented by a current source connected in shunt with a rectifying diode. For the practical application usage, connect series and shunt resistances to the ideal model as shown in Fig.3.RS represents the series intrinsic resistance whose value is very small (ideally zero) and RP represents the equivalent shunt resistance which has a very high value (ideally infinity) [10].

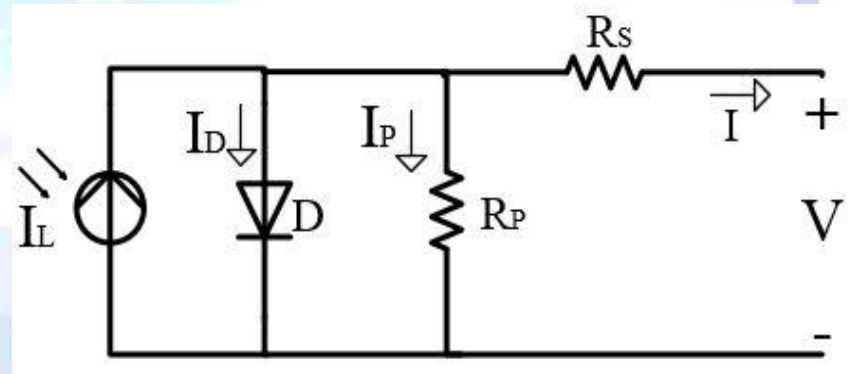

Fig.3. Equivalent circuit model of solar PV cell

From Fig.3 Applying Kirchhoff's current law

$\mathrm{IL}_{\mathrm{L}}=\mathrm{ID}+\mathrm{I} \mathrm{RP}_{\mathrm{P}}+\mathrm{I}$

The photovoltaic current equation [11]

$\mathrm{I}=\mathrm{IL}-\mathrm{I} \operatorname{RP}-\mathrm{ID}(2)$

$\mathrm{I}=\mathrm{IL}_{\mathrm{L}}$ - Io $[\exp (\mathrm{V}+\mathrm{I}$ Rs / VT) - 1] - [V + I Rs / RP]

Here, IL and Io represent the photo generated current and diode saturation current respectively, whereas I and V is the Cell current and Cell voltage respectively, $\mathrm{V}_{\text {T }}$ is the Thermal voltage. 
The V-I Characteristics represents the operating principle of a solar cell or module and indicates the relationship between the current and voltage at the present situations of temperature and irradiance. Generally the series and parallel combination of Photovoltaic cells is used to increase the voltage and current rating of solar array respectively (as shown in Fig.4) because single cell are not able to produce desired amount of capacity. V-I curves also provide the information regarding design of solar system so that it can operate as close to its best maximum efficiency as possible (as shown in Fig. 4 for parallel MPP and series MPP).

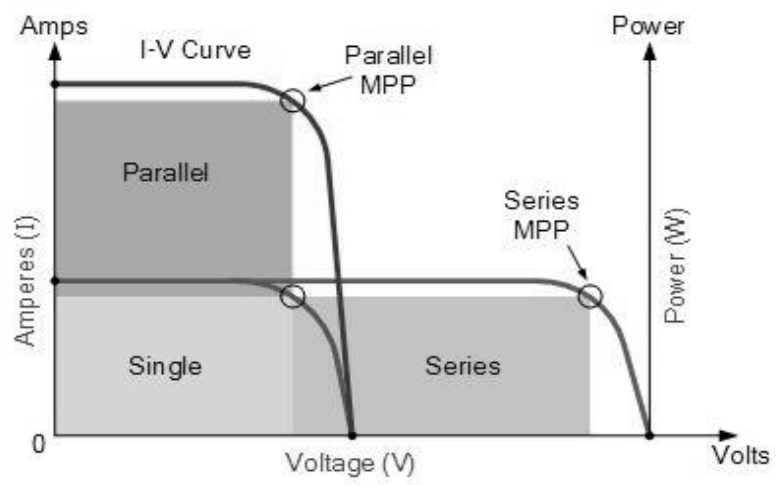

Fig.4. Variation in graph due to series and parallel connection

Solar Cell produces electrical energy in terms of DC and multiplication of current and voltage equals to power in watts, therefore make solar cell V-I curves on behalf of the current versus the voltage for a solar photovoltaic device as shown in Fig.4.

\section{CONVERTER DESCRIPTION}

The Converter step up and step down the magnitude of DC level input obtaining from solar cell to low level output DC voltage and high level output voltage respectively, so in this paper SEPIC converter is used and compare with Cuk converter.

\section{A.Cuk Converter}

Switching Cuk converter having an output voltage value (lower or higher) than the input voltage, but the output voltage of the converter has an opposite polarity with reference to input voltage [12]. The inductor $\mathrm{L}_{1}$ act as a filter on the DC side which will be used to prevent high harmonic current. The quantity of energy transferred by the Cuk Converter to the inductor is associated with the capacitor $\mathrm{C}$ shown in Fig.5.

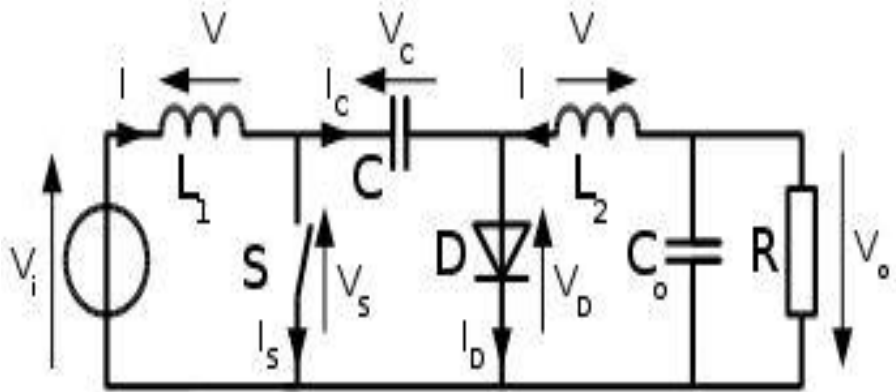

Fig.5. Basic circuit diagram of SEPIC Converter Ideally the output of Cuk converter is [13] $\mathrm{V}_{\mathrm{O}}=\{\mathrm{D} \times /(1-\mathrm{D})\} \times \mathrm{V}_{\mathrm{i}}(4)$

Where, D is the duty cycle of switching,

$\mathrm{D}=\left(\mathrm{T}_{\mathrm{ON}}\right) /(\mathrm{TON}+\mathrm{ToFF})$

In this system, the parameters of Cuk converter has been given below to get minimize value of ripple so that to attain a maximum efficiency, as follows: Inductance, $\mathrm{L}_{1}=300 \mathrm{mH}$; Inductance, $\mathrm{L}_{2}=15 \mathrm{mH}$; Capacitance, $\mathrm{C}=150$ $\mu \mathrm{F}$; Capacitance, $\mathrm{Co}=1000 \mu \mathrm{F}$ and Switching frequency, $\mathrm{f}=16 \mathrm{kHz}$.

\section{B. SEPIC Converter}

A SEPIC is conventional type of buck-boost converter, but having non-reversal output, the transformation of energy from the input side to the output side is generally passing through a series capacitor by means of coupling and when the switch is turned off output voltage drops to zero volt. The SEPIC converter permits a range of dc voltage to be adjusted to sustain a constant voltage output [14-15]. SEPIC converters can increase or decrease the voltage as per required application as shown in Fig.6.

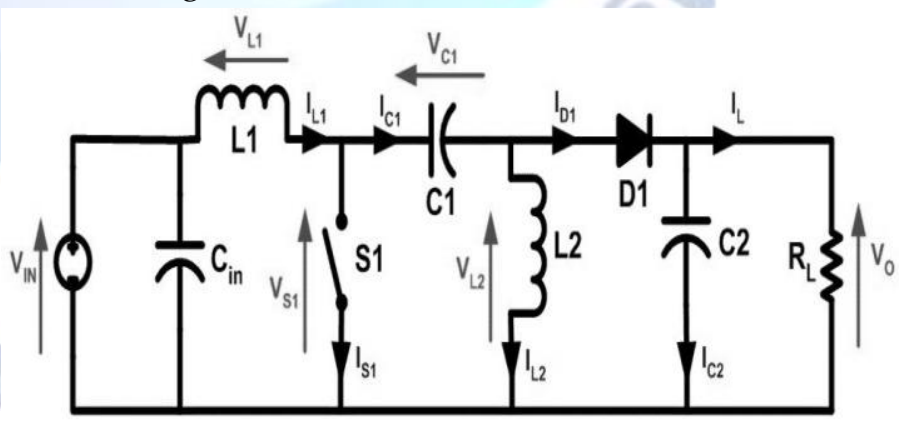

Fig.6. Basic circuit diagram of SEPIC Converter

In SEPIC converter, high triggering pulse $\mathrm{ON}$ the switch (generally MOSFET). Inductor $\mathrm{L}_{1}$ is charged by the given input voltage and with the help of capacitor $\mathrm{C}_{1}$, inductor $\mathrm{L}_{2}$ is charged as shown in Fig.7 (a). If the 
pulse triggering is low the switch is OFF, the capacitors are charged by inductors through the diode to the load output as shown Fig.7 (b). The output is maintained by capacitor 2, when diode is OFF.

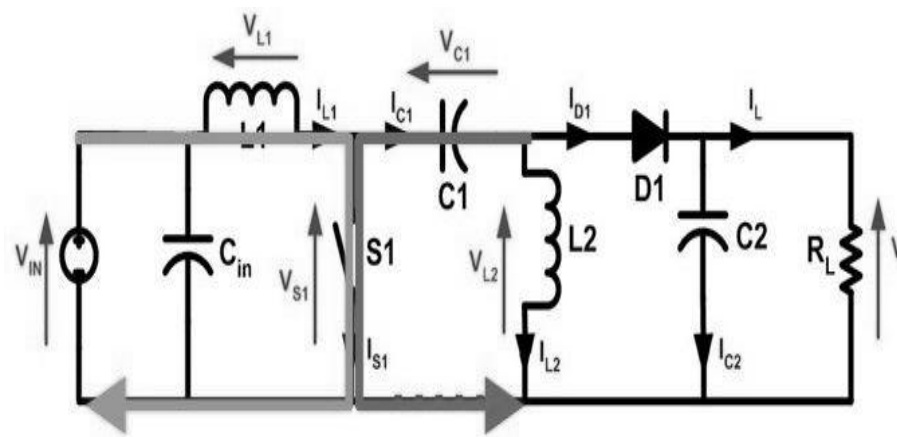

(a)

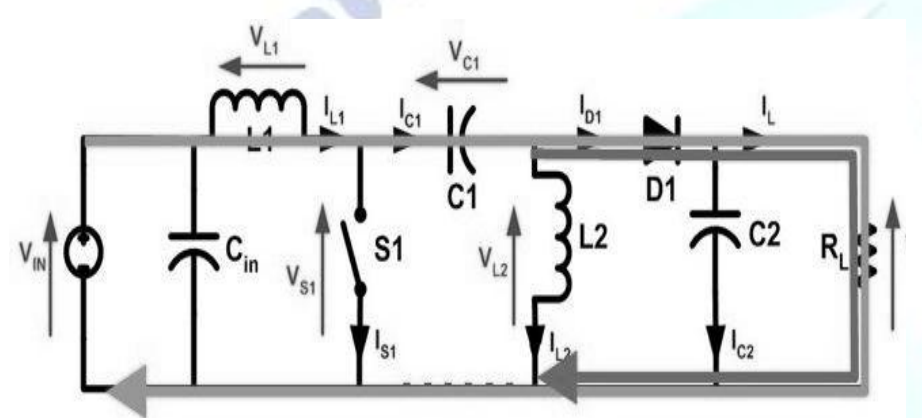

(b)

Fig.7 working circuit diagram (a) when switch $\mathrm{S} 1$ is $\mathrm{ON}$, (b) when switch $\mathrm{S} 1$ is OFF

For achievement of greater output, the pulse should be low and the percentage of duty cycle will be greater. This happened because of getting longer charging time by the inductor, hence gives greater voltage. Due to the pulse continues too long sometimes, converter fail to do the following operation thereby capacitors will not be capable to charge.

Ideally the output of SEPIC converter is

$\mathrm{V}_{\mathrm{O}}=\left(\mathrm{D} \times \mathrm{V}_{\mathrm{IN}}\right) /(1-\mathrm{D})$

In equation (6) if we consider the losses due to parasitic elements such as the diode drop $V_{D 1}$

Then, $\mathrm{V}_{\mathrm{O}}=\left\{\left(\mathrm{D} \times \mathrm{VIN}_{\mathrm{IN}}\right) /(1-\mathrm{D})\right\}-\mathrm{V}_{\mathrm{D} 1}(7)$

The amount by which step up or down of the voltage of SEPIC converter primarily depends primarily on the parasitic elements of the circuit and on applied duty cycle [16].

From equation (7) duty cycle can be,

$\mathrm{D}=\left(\mathrm{V}_{\mathrm{O}}+\mathrm{V}_{\mathrm{D} 1}\right) /\left(\mathrm{V}_{\mathrm{IN}}+\mathrm{V}_{\mathrm{O}}+\mathrm{V}_{\mathrm{D} 1}\right)$

If the duty cycle is greater than $50 \%$, it will step up the voltage and act as a boost converter whereas for duty cycle less than $50 \%$ it will be step down the voltage and act as buck converter.

In this system, the parameters of SEPIC converter has been given below to get minimize value of ripple to attain optimum efficiency, as follows: Inductance, $\mathrm{L}_{1}=$ $300 \mathrm{mH}$; Inductance, $\mathrm{L}_{2}=15 \mathrm{mH}$; Capacitance, $\mathrm{C}_{1}=150$ $\mu \mathrm{F}$; Capacitance, $\mathrm{C}_{2}=1000 \mu \mathrm{F}$.

\section{Controller for SEPIC Converter}

A PID controller is closed loop feedback controller, efforts to minimize the error among a measured process parameter and take a corrective measure by computing and then give a desire output value which can modify the process consequently. Generally it is used to minimize the dynamic response and to decrease the steady-state error [17]. The current error reaction determines by the Proportional (P), the sum of recent errors reaction determines by the Integral (I) and the rate at which the error has been varying determines by the Derivative (D).

In a feedback closed loop the PID controller output signal given by

$u(t)=K_{p} e+K_{i} \int e d t+K_{d}(d e / d t)$

This control signal will be fed to the plant/process, and the new output $y(t)$ will be attained. This new output will be then sent back again to the feedback control sensor, to find the new error signal $\mathrm{e}(\mathrm{t})$ [18]. The controller precedes this novel error as input signal and calculates the gain values $\left(\mathrm{K}_{\mathrm{p}}, \mathrm{K}_{\mathrm{i}}, \mathrm{K}_{\mathrm{d}}\right)$ as shown in Fig. 8.

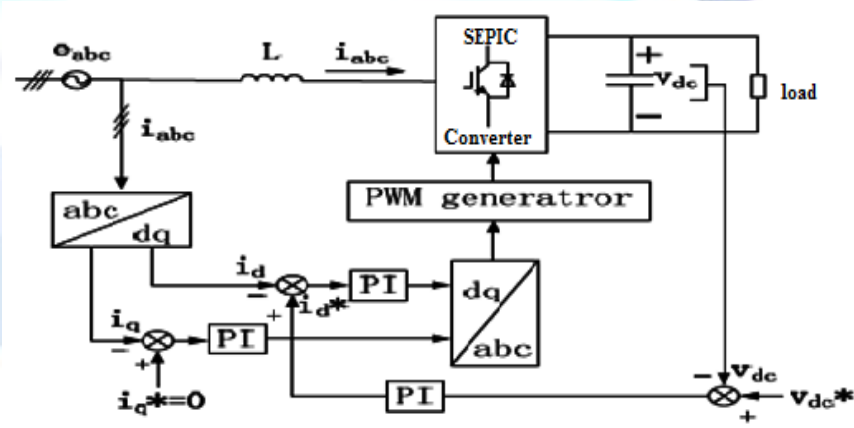

Fig.8. Schematic diagram of control strategy

In this system, the parameter of $\mathrm{Kp}, \mathrm{Ki}$ and $\mathrm{Kd}$ are $0.001,100$ and 0 respectively, increases the performance and efficiency of converter. Here the whole control strategy includes two loops current inner loop and voltage outer loop and switching pulse to the MOSFET has been provide by the Pulse Width Modulation technique, by comparing a constant dc voltage i.e. reference value with a saw tooth signal i.e. carrier value 
and the switching frequency has been taken as $16 \mathrm{kHz}$.

\section{INVERTER DESCRIPTION}

The configured system is designed for the purpose of domestic load that's why the single phase full bridge VSI is used for the conversion operation of DC output, obtaining from SEPIC converter to the AC output for full fill the required needs of desired load.

\section{A. Single Phase Full Bridge VSI}

The inverter converts DC power to $\mathrm{AC}$ power by providing the DC input voltage or current in a pre-defined sequential arrangement so as to produce AC voltage or current output. The single phase full bridge inverter involves a two arms with a two semiconductor switches on both arms and having antiparallel freewheeling diodes with each switch for discharging the reverse current [19]. Generally in the case of RL load equipment, these diodes allow to flow reverse load current through it and these diodes also provide an alternative route to inductive current which remain so run during the Turn OFF situation as shown in Fig.9.

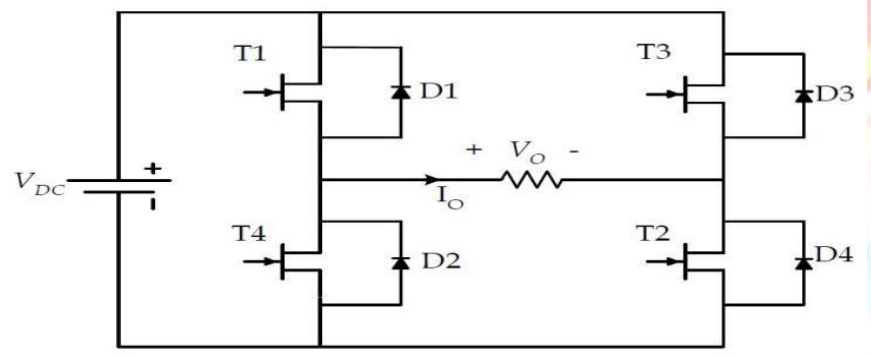

Fig.9. Basic circuit diagram of single phase full-bridge

VSI

From Fig. 9, the switches are $T_{1}, T_{2}, T_{3}$ and $T_{4}$ with antiparallel freewheeling didoes $\mathrm{D}_{1}, \mathrm{D}_{2}, \mathrm{D}_{3}$ and $\mathrm{D}_{4}$. The switches are alternatively operated in way on each branch so that they are not simultaneously ON and OFF in same mode. To avoid short circuiting, In general both the switch is OFF for very short duration of time called blanking time. To get the desired output the switches should be operate in $T_{1}$ and $T_{2}$ or $T_{3}$ and $T_{4}$ pair to get the desired output. For the change in polarity of voltage waveform, the bridges legs are switched in a manner by which the output voltage is shifted from one to another. When the output voltage is max, then shift angle is $\pi$ and if the output voltage is zero, then shift angle is also zero. The circuit operation, when S1, S2 ON and S3, S4
OFF for duration $t 1<t<t 2$ as shown in Fig.10 (a) and when S1, S2 OFF and S3, S4 ON for duration $\mathrm{t} 2<\mathrm{t}<\mathrm{t} 3$ as shown in Fig.10 (b).

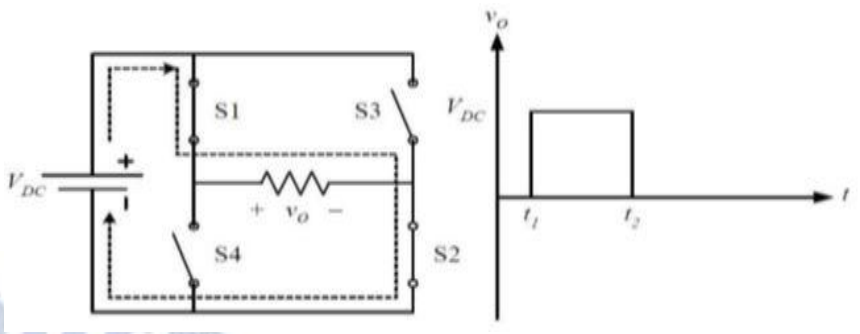

(a)

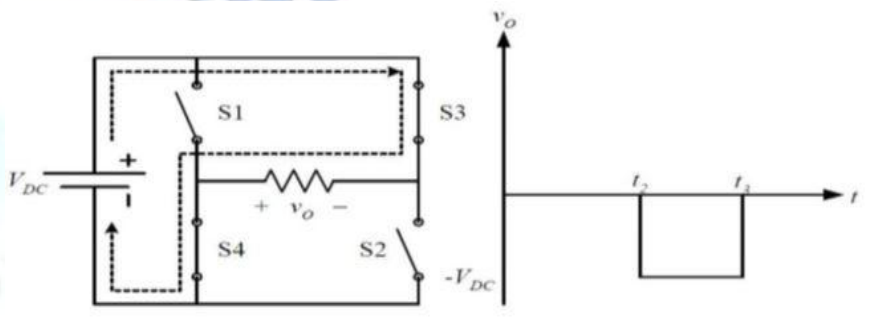

(b)

Fig. 10 Working circuit diagram (a) when S1, S2 ON, (b) when S3, S4 ON

For the better conversion of power from $\mathrm{DC}$ to $\mathrm{AC}$ with minimum losses and low THD in output has been achieved by the Pulse Width Modulation technique to provide switching pulses to the MOSFET accurately [20-21]. The values given to PWM pulse generator for output voltage frequency, carrier frequency and modulation index are $50 \mathrm{~Hz}, 1030 \mathrm{~Hz}$ and 1 respectively and also the value given to the RL load (domestic load) having resistance is $50 \Omega$ and inductance is $100 \mathrm{mH}$.

\section{RESULTS}

The MATLAB/SPS software has been used to simulate the solar energy based DC-AC system with using Cuk converter to DC-DC conversion of power from solar cells and then using single phase full bridge VSI to DC-AC conversion as shown in Fig. 11.

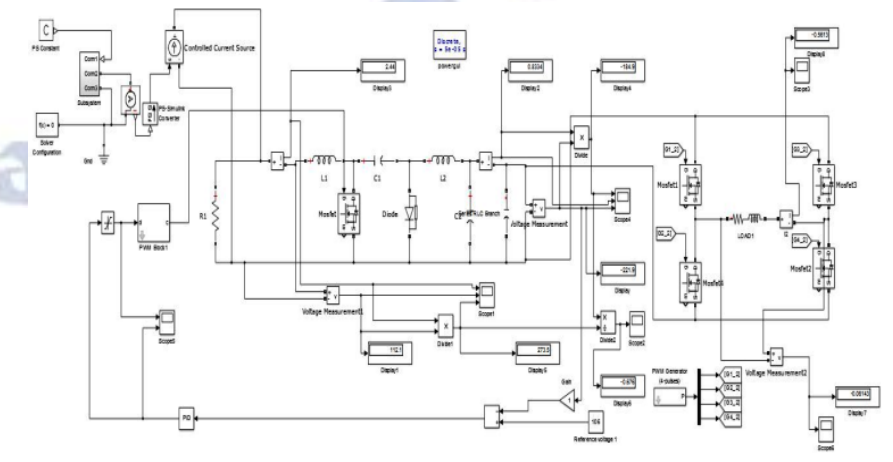

Fig. 11 MATLAB Simulink model of Solar PV based Cuk with VSI 
A.Simulated Output Graphs of Solar PV cells for Cuk Converter Input

The simulated waveform obtained by the MATLAB/SPS software in which the input current Cuk converter is $3.989 \mathrm{~A}$, that is also the output current from the solar cells as shown in Fig. 12(a) and Similarly input voltage for Cuk converter is $112.6 \mathrm{~V}$, that is also the output voltage from the solar cells as shown in Fig. 12(b).

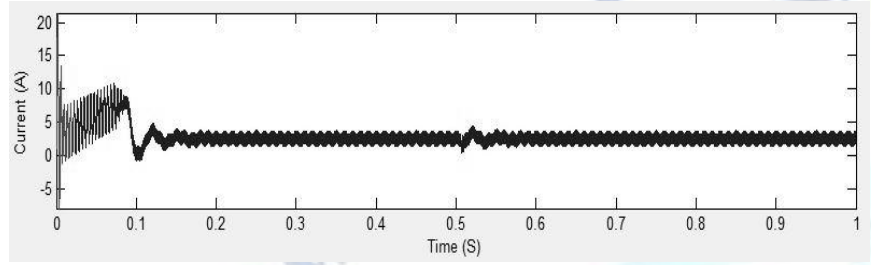

(a)

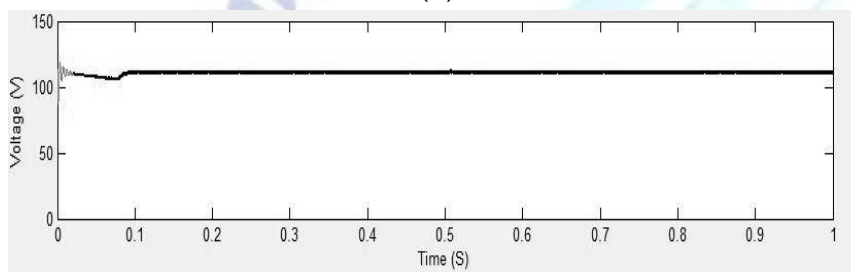

(b)

Fig. 12 Solar PV cells outputs and Cuk Inputs (a)

Current versus Time (b) Voltage versus Time

B. Simulated Output Graphs of Cuk Converter for Inverter Input

The simulated waveform obtained by the MATLAB/SPS software in which the input current for single phase full bridge VSI is $-2.457 \mathrm{~A}$, that is also the output current from the Cuk converter as shown in Fig. 13(a) and Similarly input voltage for single phase full bridge VSI is $-221.5 \mathrm{~V}$, that is also the output voltage from the SEPIC converter as shown in Fig. 13(b).

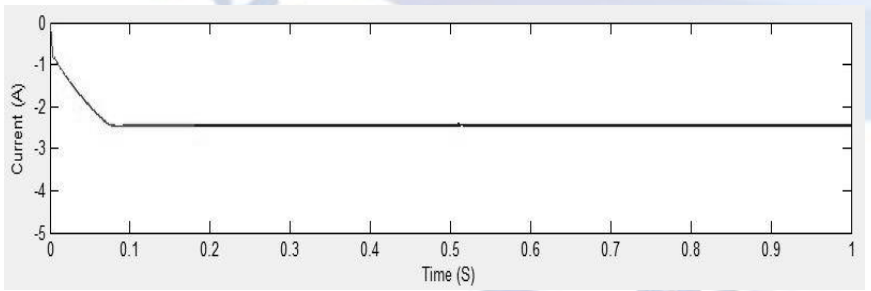

(a)

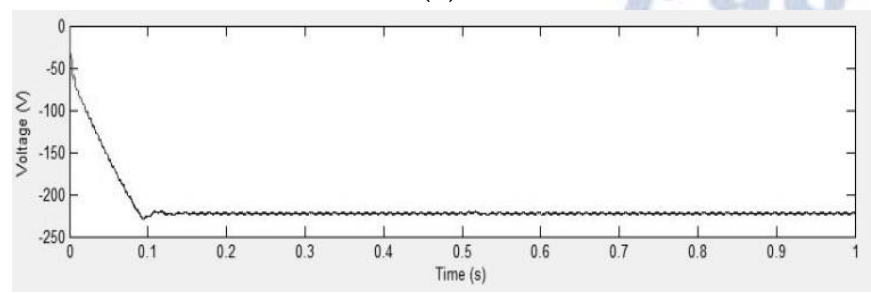

(b)

Fig. 13 Cuk outputs and Inverter Inputs (a) Current versus Time (b) Voltage versus Time
C. Simulated Output Graphs of Solar PV based Cuk with VSI for Domestic Load Input

The simulated waveform obtained by the MATLAB/SPS software in which the input current for domestic load (RL load) is $2.171 \mathrm{~A}$, that is also the output current from the single phase full bridge VSI as shown in Fig. 14(a) and Similarly input voltage for domestic load (RL load) is $221.1 \mathrm{~V}$, that is also the output voltage from the single phase full bridge VSI as shown in Fig. 14(b).

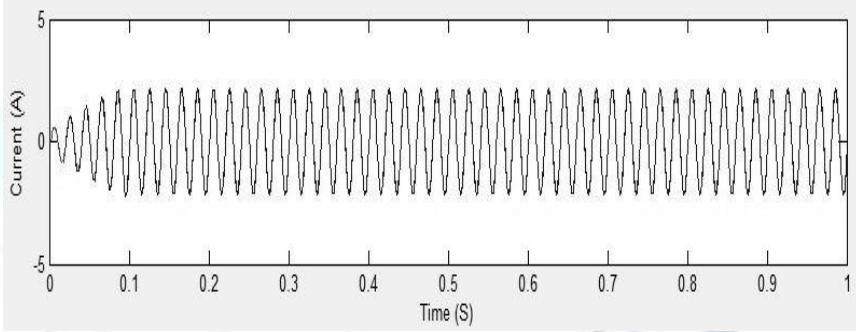

(a)

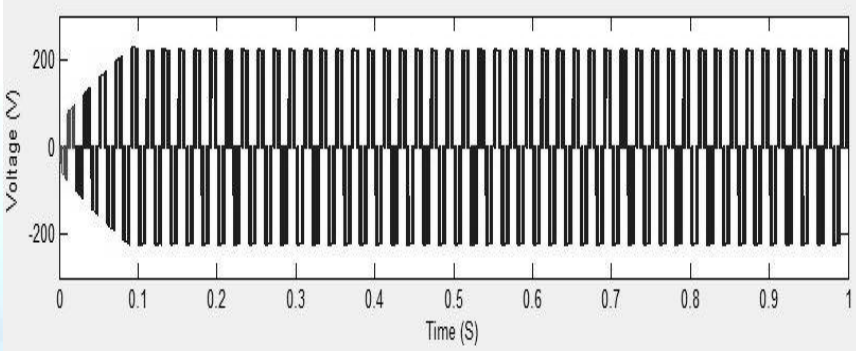

(b)

Fig. 14 Cuk with VSI outputs and Domestic load Inputs

(a) Current versus Time (b) Voltage versus Time

D. Total Harmonic Distortion in Output Voltage of Solar PV based Cuk with VSI

The simulated graph of total harmonic distortion obtained by the MATLAB/SPS software in which the THD present in the voltage is $10.00 \%$ for the solar energy based DC-AC by using closed loop Cuk converter with single phase full bridge VSI for the domestic load as shown in Fig. 15.

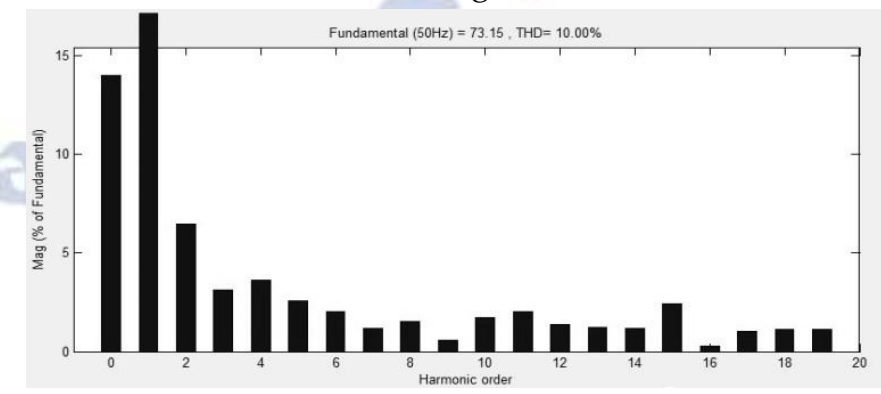

Fig. 15 THD in output voltage of solar PV based Cuk with VSI for DC-AC domestic load system

The MATLAB/SPS software has been used to simulate the solar energy based DC-AC system with 
using SEPIC converter to DC-DC conversion of power from solar cells and then using single phase full bridge VSI to DC-AC conversion as shown in Fig. 16.

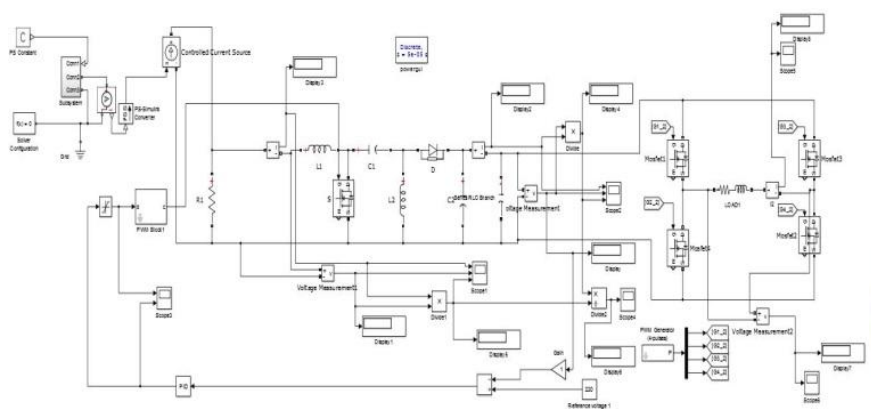

Fig. 16 MATLAB Simulink model of Solar PV based SEPIC with VSI

E. Simulated Output Graphs of Solar PV cells for SEPIC Converter Input

The simulated waveform obtained by the MATLAB/SPS software in which the input current for SEPIC converter is $5.160 \mathrm{~A}$, that is also the output current from the solar cells as shown in Fig. 17(a) and Similarly input voltage for SEPIC converter is $112.4 \mathrm{~V}$, that is also the output voltage from the solar cells as shown in Fig. 17(b).

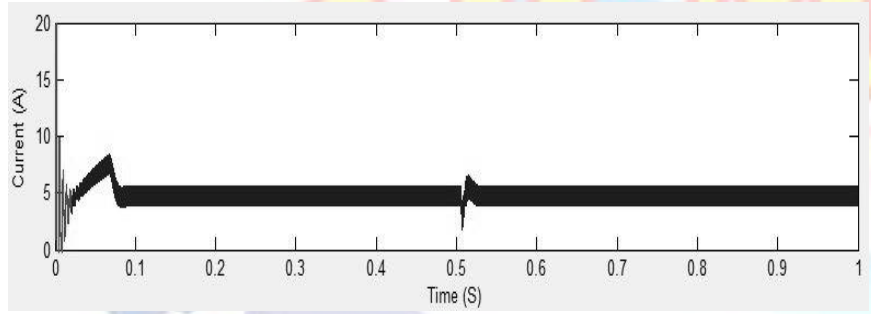

(a)

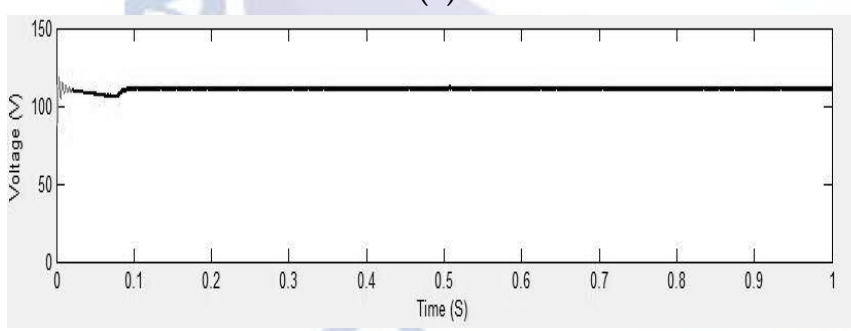

(b)

Fig. 17 Solar PV cells outputs and SEPIC Inputs (a)

Current versus Time (b) Voltage versus Time

F. Simulated Output Graphs of SEPIC Converter for Inverter Input

The simulated waveform obtained by the MATLAB/SPS software in which the input current for single phase full bridge VSI is $2.461 \mathrm{~A}$, that is also the output current from the SEPIC converter as shown in Fig. 18(a) and Similarly input voltage for single phase full bridge inverter is $222.9 \mathrm{~V}$, that is also the output voltage from the SEPIC converter as shown in Fig. 18(b).

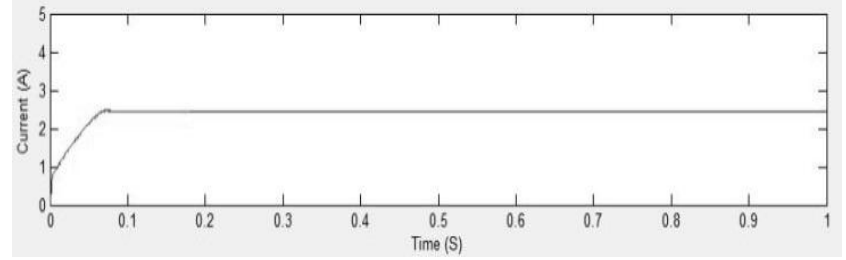

(a)

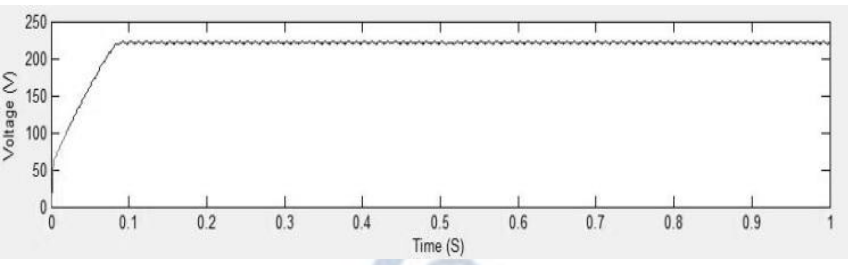

(b)

Fig. 18 SEPIC outputs and Inverter Inputs (a) Current versus Time (b) Voltage versus Time

G. Simulated Output Graphs of Solar PV based SEPIC with VSI for Domestic Load Input

The simulated waveform obtained by the MATLAB/SPS software in which the input current for domestic load (RL load) is $2.281 \mathrm{~A}$, that is also the output current from the single phase full bridge VSI as shown in Fig. 19(a) and Similarly input voltage for domestic load (RL load) is $222.6 \mathrm{~V}$, that is also the output voltage from the single phase full bridge VSI as shown in Fig. 19(b).

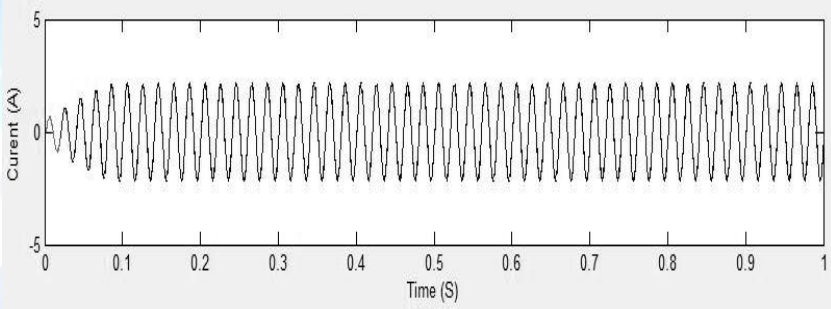

(a)

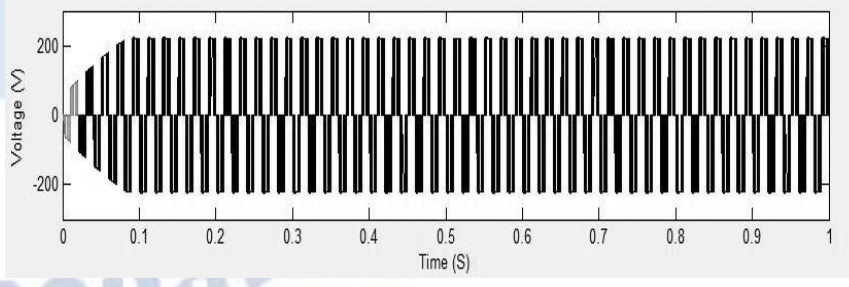

(b)

Fig. 19 Inverter outputs and Domestic load Inputs (a) Current versus Time (b) Voltage versus Time

H. SimulatedTotal Harmonic Distortion in Output Voltage of Solar PV based SEPIC with VSI

The simulated graph of total harmonic distortion obtained by the MATLAB/SPS software in which the THD present in the voltage is $8.03 \%$ for the solar energy 
based DC-AC by using closed loop SEPIC converter with single phase full bridge VSI for the domestic load as shown in Fig. 20.

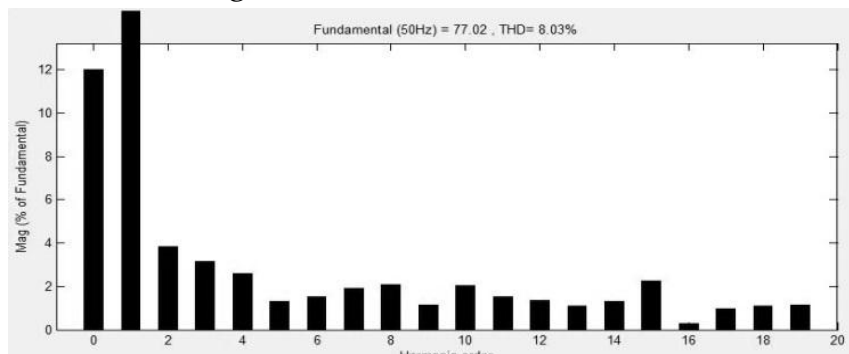

Fig. 20 THD in output voltage for solar energy based DC-AC system for domestic load

I. SimulatedComparative analysis of solar energy based DC-AC system

The overall variation obtained by the MATLAB/SPS software for voltage and current parameter form input to output and also THD of Cuk converter with VSI and SEPIC converter with VSI for designed configured DC-AC system as shown in table 1.

Table I. Analysis of DC-AC solar energy system for domestic load

\begin{tabular}{|c|c|c|c|c|}
\hline \multirow{2}{*}{\begin{tabular}{c} 
Variable \\
\cline { 2 - 5 }
\end{tabular}} & \multicolumn{3}{|c|}{ Solar DC-AC system } \\
\cline { 2 - 5 } & \multicolumn{2}{|c|}{$\begin{array}{c}\text { Cuk Converter } \\
\text { with VSI }\end{array}$} & \multicolumn{2}{|c|}{$\begin{array}{r}\text { SEPIC Converter } \\
\text { with } \text { VSI }\end{array}$} \\
\hline $\begin{array}{c}\text { Voltage } \\
\text { (V) }\end{array}$ & 112.6 & 221.1 & 112.4 & 222.6 \\
\hline $\begin{array}{c}\text { Current } \\
\text { (A) }\end{array}$ & 3.989 & 2.171 & 5.160 & 2.281 \\
\hline THD\% & \multicolumn{2}{|c|}{$10.00 \%$} & \multicolumn{2}{|c|}{$8.03 \%$} \\
\hline
\end{tabular}

\section{CONCLUSION}

In this paper, the efficient solar PV based closed loop SEPIC converter with single phase full bridge VSI (DC-AC) system is designed and simulated in MATLAB/SPS software and also compare by solar PV based closed loop Cuk converter with single phase full bridge VSI system for the domestic load (RL load). In which for given $R L$ load $(R=50 \Omega$ and $L=100 \mathrm{mH})$, the low DC input voltage $(112.4 \mathrm{~V})$ from solar PV cells is boost up by the SEPIC converter to high DC input voltage $(222.9 \mathrm{~V})$ for inverter and then this DC input voltage converted to AC output voltage (222.9 V) with low THD $(8.03 \%)$ by the Single phase full bridge VSI as desired for the reliable operation of domestic load with low losses.

\section{REFERENCES}

[1] Y. V. P. Kumar and R. k. Bhimasingu (2015), "Renewable energy based microgrid system sizing and energy management for green buildings," Springer Journal of Modern Power Systems and Clean Energy, Vol. 3, No. 1, pp.1-13.

[2] S. Kumar and B. Dwivedi (2019), "Techno-economical Study of Power System Market- A Game Theory Approach," International Conference on Automation, Computational and Technology Management (ICACTM), pp. 84-88.

[3] S. Kumar, B. Dwivedi, N. A. Shrivastava (2021). "Profit evaluation inclusive of reserve pricing for renewable-integrated GENCOs" International Journal of Emerging Electric Power Systems, Vol. 22, No.4, pp. 1-11.

[4] R. Singh, S. Kumar and S. Chauhan (2013), "Energy:-Conservation, Management, Efficiency \& Storage," International Journal of Applied Engineering Research (IJAER), Vol. 8 No. 7, pp. 80-85.

[5] Y. J. Reddy, Y. V. P. Kumar, K. P. Raju, and A. Ramsesh (2012), "Retrofitted hybrid power system design with renewable energy sources for buildings," IEEE Trans. Smart Grid, Vol. 3, No. 4, pp. 2174-2187.

[6] J. M. Guerrero, F. Blaabjerg, T. Zhelev, et. al. (2010), “Distributed generation: Toward a new energy paradigm," IEEE Industrial Electronics Mag., Vol. 4, No. 1, pp. 52-64.

[7] S. Kumar, B. Dwivedi and N. A. Shrivastava (2021), "A Game Theory Strategy-Based Bidding Evaluation for Power Generation Market," IEEE Canadian Journal of Electrical and Computer Engineering, Vol. 44, No. 3, pp. 283-288.

[8] M. Patterson, N. F. Macia and A. M. Kannan (2015), "Hybrid Microgrid Model Based on Solar Photovoltaic Battery Fuel Cell System for Intermittent Load Applications," in IEEE Transactions on Energy Conversion, Vol. 30, No. 1, pp. 359-366.

[9] S. Kumar, R. Kumar and N. Singh (2017), "Performance of closed loop SEPIC converter with DC-DC converter for solar energy system," 4th International Conference on Power, Control \& Embedded Systems (ICPCES), Allahabad, India, pp. 1-6.

[10] W. Chen, Y. Duan, L. Guo, Y. Xuan and X. Yang (2016), "Modeling and Prediction of Radiated Emission From Solar Cell in a Photovoltaic Generation System," in IEEE Journal of Photovoltaics, Vol. 6, No. 2, pp. 540-545.

[11] S. Nema, R. K. Nema, G. Agnihotri (2010), "MATLAB/Simulink based study of photovoltaic cells / modules / array and their experimental verification", International journal of Energy and Environment, Vol.1, No.3, pp.487-500.

[12] S. Kumar and N .Singh (2016), "Comparatively Analysis of DC-DC Converter for Solar Energy System" National Conference on Electrical Power Technology, Management and IT Applications (EPTMITA), Gorakhpur, India, pp. 1-6.

[13] R. Kumar and B. Singh (2017), "Solar PV powered BLDC motor drive for water pumping using Cuk converter," in IET Electric Power Applications, Vol. 11, No. 2, pp. 222-232.

[14] R. Kumar, S. Kumar, N. Singh and V. Agrawal (2017), "SEPIC converter with 3-level NPC multi-level inverter for wind energy system (WES)," 4th International Conference on Power, Control \& Embedded Systems (ICPCES), Allahabad, India, pp. 1-6.

[15] R. Kumar, S. Kumar and N. Singh (2017) "A Comparative Study of PWM Rectifier and Diode Rectifier -Fed SEPIC Converter for Wind Energy Conversion System" International Conference on Challenges in Sustainable Development from Energy \& Environment Perspective (CSDEEP), Gorakhpur, India, pp. 256-265.

[16] E. Babaei and M. E. Seyed Mahmoodieh (2014), "Calculation of Output Voltage Ripple and Design Considerations of SEPIC Converter," in IEEE Transactions on Industrial Electronics, Vol. 61, No. 3, pp. 1213-1222. 
[17] R. Arulmurugan, N. Suthanthira Vanitha (2012),“Optimal design of DC to DC boost converter with closed loop control PID mechanism for high voltage photovoltaic application", International Journal of Power Electronics and Drive System, Vol.2, No.4, pp. 434-444.

[18] P. S. Subramanian, and R. Kayalvizhi (2015), "An Optimum Setting of PID Controller for Boost Converter Using Bacterial Foraging Optimization Technique", Lecture Notes in Electrical Engineering.

[19] F. L. Tofoli and C. A. Gallo (2016), "Analysis, design, and implementation of soft-switching cells applied to the single-phase full-bridge inverter," in IET Power NElectronics, Vol. 9, no. 6, pp. 1249-1258.

[20] Z. J. Shen, Y. Xiong, X. Cheng, Y. Fu, and P. Kumar (2006), "Power MOSFET switching loss analysis: A new insight," in Proc. IEEE Ind. Appl. Conf., Tampa, FL, USA, pp. 1438-1442.

[21] S. Dalapati and C. Chakraborty (2008), "A Direct PWM Technique for a Single-Phase Full-Bridge Inverter Through Controlled Capacitor Charging," in IEEE Transactions on Industrial Electronics, Vol. 55, No. 8, pp. 2912-2922. 